\title{
Optimization of analgesia for piglet castration under isoflurane anaesthesia with parenteral butorphanol, meloxicam or intratesticular lidocaine
}

\author{
Hug, Petra Julia ; Cap, V H ; Honegger, J ; Schüpbach-Regula, Gertraud ; Schwarz, Andrea ; \\ Bettschart-Wolfensberger, Regula
}

\begin{abstract}
This blinded prospective study investigated analgesic effects of intramuscular (IM) butorphanol, meloxicam or intratesticular (IT) lidocaine for castration of 7-14 days old piglets under isoflurane anaesthesia. 66 piglets were randomly injected with: meloxicam IM (0.4 mg/kg; group M), butorphanol IM ( $0.2 \mathrm{mg} / \mathrm{kg}$; group B), or both (group BM) 20 minutes prior to castration, or lidocaine IT ( $4 \mathrm{mg} / \mathrm{kg}$ (group ML4) or $8 \mathrm{mg} / \mathrm{kg}$ (group ML8)) together with meloxicam IM $(0.4 \mathrm{mg} / \mathrm{kg})$ under anaesthesia with $1.8 \%$ end-tidal isoflurane. Heart rate, respiratory rate, mean arterial blood pressure and end-tidal carbon dioxide were recorded. Anaesthesia quality was scored and postoperative behaviour assessed. As butorphanol caused unacceptable side effects, its use was stopped. Group M showed worse anaesthesia quality than ML4 and ML8 (higher incidence of movements: 11/17, 3/18 and $4 / 17$, respectively). There were no significant differences between groups regarding parameters measured during castration. Postoperative behaviour did not differ between groups. For castration of 7-14 days old piglets under isoflurane anaesthesia, IT lidocaine provides an additional side effect free analgesia.
\end{abstract}

DOI: https://doi.org/10.17236/sat00169

Other titles: Optimierung der Analgesie für Ferkelkastrationen unter Isoflurananästhesie mit parenteralem Butorphanol, Meloxicam oder intratestikulärem Lidocain

Posted at the Zurich Open Repository and Archive, University of Zurich ZORA URL: https://doi.org/10.5167/uzh-152342

Journal Article

Published Version

Originally published at:

Hug, Petra Julia; Cap, V H; Honegger, J; Schüpbach-Regula, Gertraud; Schwarz, Andrea; Bettschart-Wolfensberger, Regula (2018). Optimization of analgesia for piglet castration under isoflurane anaesthesia with parenteral butorphanol, meloxicam or intratesticular lidocaine. Schweizer Archiv für Tierheilkunde, 160(7-8):461-467.

DOI: https://doi.org/10.17236/sat00169 


\title{
Optimization of analgesia for piglet castration under isoflurane anaesthesia with parenteral butorphanol, meloxicam or intratesticular lidocaine
}

\author{
P. J. Hug1', V.H. Cap1', J. Honegger², G. Schüpbach-Regula3, A. Schwarz¹, \\ R. Bettschart-Wolfensberger ${ }^{1}$
}

1 Section Anaesthesiology, Department of Clinical Diagnostics and Services and ${ }^{2}$ Division of Swine Medicine, Department for Farm Animals, Vetsuisse Faculty, University of Zurich, Switzerland ${ }^{3}$ Veterinary Public Health Institute, Vetsuisse Faculty, University of Berne, Switzerland

\begin{abstract}
This blinded prospective study investigated analgesic effects of intramuscular (IM) butorphanol, meloxicam or intratesticular (IT) lidocaine for castration of 7-14 days old piglets under isoflurane anaesthesia. 66 piglets were randomly injected with: meloxicam IM $(0.4 \mathrm{mg} / \mathrm{kg}$; group $\mathrm{M})$, butorphanol IM $(0.2 \mathrm{mg} / \mathrm{kg}$; group $\mathrm{B})$, or both (group BM) 20 minutes prior to castration, or lidocaine IT (4 mg/kg (group ML4) or $8 \mathrm{mg} / \mathrm{kg}$ (group ML8)) together with meloxicam IM $(0.4 \mathrm{mg} / \mathrm{kg})$ under anaesthesia with $1.8 \%$ end-tidal isoflurane. Heart rate, respiratory rate, mean arterial blood pressure and end-tidal carbon dioxide were recorded. Anaesthesia quality was scored and postoperative behaviour assessed. As butorphanol caused unacceptable side effects, its use was stopped. Group M showed worse anaesthesia quality than ML4 and ML8 (higher incidence of movements: $11 / 17,3 / 18$ and $4 / 17$, respectively). There were no significant differences between groups regarding parameters measured during castration. Postoperative behaviour did not differ between groups. For castration of 7-14 days old piglets under isoflurane anaesthesia, IT lidocaine provides an additional side effect free analgesia.
\end{abstract}

Keywords: local anaesthesia, inhalation anaesthesia, swine

Optimierung der Analgesie für Ferkelkastrationen unter Isoflurananästhesie mit parenteralem Butorphanol, Meloxicam oder intratestikulärem Lidocain

Diese prospektive Blindstudie untersuchte den analgetischen Effekt von intramuskulärem (IM) Butorphanol, Meloxicam oder intratestikulärem (IT) Lidocain für die Kastration von 7 bis 14-tägigen Ferkeln unter Isoflurananästhesie. 66 Ferkel wurden zufällig injziert mit: Meloxicam IM (0.4 mg/kg; Gruppe M), Butorphanol IM $(0.2 \mathrm{mg} / \mathrm{kg}$; Gruppe B), oder beidem (Gruppe MB) 20 Minuten vor Kastration, oder Lidocain IT $(4 \mathrm{mg} / \mathrm{kg}$ (Gruppe ML4), oder $8 \mathrm{mg} / \mathrm{kg}$ (Gruppe ML8)) und Meloxicam IM $(0.4 \mathrm{mg} / \mathrm{kg})$ unter $1.8 \%$ end-tidaler Isoflurananästhesie. Herzfrequenz, Atemfrequenz, mittlerer arterieller Blutdruck und end-tidales Kohlendioxid wurden dokumentiert. Die Anästhesiequalität wurde beurteilt und das postoperative Verhalten beobachtet. Butorphanol verursachte unakzeptable Nebenwirkungen und seine Verwendung wurde gestoppt. Gruppe M zeigte schlechtere Anästhesiequalität als ML4 und ML8 (höhere Inzidenz von Bewegungen: 11/17, $3 / 18$ und 4/17). Übrige intraoperative Parameter zeigten keine signifikanten Unterschiede und beim postoperativen Verhalten wurden keine Unterschiede zwischen den Gruppen erkannt. Für die Kastration von 7-14 tägigen Ferkeln unter Isoflurananästhesie bietet IT appliziertes Lidocain eine zusätzliche, nebenwirkungsfreie Analgesie.

Schlüsselwörter: Lokalanästhesie, Inhalationsanästhesie, Schwein https://doi.org/ $10.17236 /$ sat00169

Received: 20.10 .2017 Accepted: 14.02 .2018 
Optimization of analgesia for piglet castration under isoflurane anaesthesia with parenteral butorphanol, meloxicam or intratesticular lidocaine

P.J. Hug et al.

\section{Introduction}

In Switzerland, 1.3 millions male piglets are castrated yearly, 75\% under inhalation anaesthesia (Enz et al., 2013). Isoflurane is a volatile agent providing fast and save induction of anaesthesia in pigs (Hodgson, 2007). As it lacks analgesic properties (Petersen-Felix et al., $1995)$ it does not reduce stress response to castration (Schulz, 2007). With additional administration of a non-steroidal anti inflammatory drug (NSAID) such as meloxicam, stress response is reduced (Schulz, 2007). Furthermore, piglets receiving meloxicam show less pain related behaviour during and after surgery (Zöls, 2006; Hansson et al., 2011). However, in a Swiss survey 22\% of piglets castrated under isoflurane anaesthesia including meloxicam, showed movement during castration (Enz et al., 2013). A German study showed an even higher number of insufficient depth of anaesthesia with $34 \%$ (Steigmann, 2013).

To improve analgesia during castration under inhalation anaesthesia, local anaesthesia could be used. With local anaesthesia, blockade of nociceptive transmission should result in pain relief (Vandermeulen, 2000). It has been shown in awake piglets, that intraoperative vocalisation and defence movements are reduced using intratesticular (IT) or subcutaneous lidocaine, in comparison to no analgesia (Hansson et al., 2011). In piglets castrated under halothane anaesthesia, mean arterial blood pressures raised significantly less with local anaesthesia and fewer pain-related changes in EEG were seen (Haga and Ranheim, 2005). Otherwise, literature concerning perioperative pain reduction using local anaesthesia for castration of awake piglets is controversial. Procaine IT in comparison to no analgesia for castration of awake piglets did not result in a reduction of neuroendocrine stress response post operatively, or even an increased stress response was described (Zöls, 2006; Zankl et al., 2007). In contrast, piglets receiving lidocaine IT compared to no analgesia or meloxicam only, showed a lower increase in postoperative plasma cortisol levels (Kluivers-Poodt et al., 2012). An even better outcome was seen in a recently published study using a combination of parenteral meloxicam and IT and subcutaneous lidocaine (Bonastre et al., 2016).

Another option to improve perioperative analgesia is the use of butorphanol, a central acting opioid (Riviere and Papich, 2009), that was reported to have beneficial effects in piglets castrated under injection anaesthesia (Nussbaumer et al., 2011).

The aim of this study was to investigate the effects of additional IM buorphanol or IT lidocaine on the intraoperative response to castration of piglets under isoflurane anaesthesia including parenteral meloxicam as well as the effect on postoperative behaviour.

\section{Animals, Material and Methods}

\section{Animals}

The study was approved by the veterinary office of the Canton of Zurich (081/2016).

66 male mixed breed piglets aged between 7 and 14 days were included in this study and by means of an online randomization tool allocated to 5 groups.

\section{Anaesthesia protocol}

Twenty minutes prior to castration, Group $M$ was injected meloxicam $0.4 \mathrm{mg} / \mathrm{kg}\left(\right.$ Metacam $^{\circledR}$, Boehringer Ingelheim, Germany) IM, Group B received butorphanol $0.2 \mathrm{mg} / \mathrm{kg}$ (Butomidor ${ }^{\circledR}$, Streuli, Uznach, Switzerland) IM and Group MB received meloxicam and butorphanol $(0.4 \mathrm{mg} / \mathrm{kg}$, respectively $0.2 \mathrm{mg} / \mathrm{kg}$ ) IM. Group ML4 and ML8 received either $4 \mathrm{mg} / \mathrm{kg}$ or $8 \mathrm{mg} / \mathrm{kg}$ lidocaine (Lidocain $2 \%{ }^{\circledR}$, Streuli, Uznach, Switzerland) IT together with meloxicam $(0.4 \mathrm{mg} / \mathrm{kg})$ IM just before castration, under inhalation anaesthesia. A person not involved in the study evaluation performed all injections. The person judging the quality of castration and recording the vital parameters was blinded to group allocation through the entire trial.

\section{Anaesthesia monitoring}

All male piglets from each litter were separated from females. The person responsible for drug administration estimated the weight of the piglets and administered the drugs in a random order (in groups $\mathrm{M}, \mathrm{B}$, and $\mathrm{MB}$ ). After 20 minutes, anaesthesia was induced by mask with $5 \%$ isoflurane (initial vaporizer setting, Attane ${ }^{\mathrm{TM}}$, Piramal Healthcare, Limited, India) and a flow of $2 \mathrm{~L} / \mathrm{min}$ of $\mathrm{O}_{2}$. The piglets were placed in dorsal recumbency and instrumented with ECG, pulse oxymetry $\left(\mathrm{SpO}_{2}\right)$, oscillometric blood pressure measurement device (Dinamap Carescape ${ }^{\mathrm{TM}}$ V100 vital sign monitor, GE Healthcare, Buckinghamshire, Great Britain) with a cuff positioned over the right front limb metacarpal artery, and a capnograph tube, which was placed $0.5 \mathrm{~cm}$ inside the piglet's nostril. Two minutes after the onset of isoflurane the following parameters were recorded: heart rate (HR), respiratory rate $(\mathrm{RR})$, mean arterial blood pressure (MAP), end-tidal $\mathrm{CO}_{2}\left(\mathrm{EtCO}_{2}\right)$ and end-tidal isoflurane (EtIso) (Datex-Ohmeda S/5, GE Healthcare, Buckinghamshire, Great Britain). Subsequently, the isoflurane vaporizer was adjusted to maintain EtIso of $1.8 \pm 0.1 \%$, the fresh gas flow of $\mathrm{O}_{2}$ remained constant. Piglets of group ML4 and ML8 were then injected lidocaine IT and meloxicam IM.

\section{Quality of anaesthesia and analgesia}

One minute thereafter, the blinded observer judged reaction to insertion of a $22 \mathrm{G}$ needle into each testicle (performed in duplicate) with a scoring system (Tab. 1) 
described by Berchtold (2015). Simultaneously, the vital parameters mentioned above were recorded. If number of movements or intensity of movement was $<2$, castration was performed. Otherwise an additional minute was deferred and the same procedure was repeated. This was carried out for 10 minutes in one-minute intervals. If the piglet still showed a score $\geq 2$, butorphanol $0.2 \mathrm{mg} / \mathrm{kg}$ IM was administered and the piglet castrated. During castration the following steps were distinguished: 1) incision above both testicles, without opening the processus vaginalis (defined as "cut"), 2) exteriorization of testicles ("exteriorization") and 3) "emasculation" performed simultaneously in both testicles. During each step, monitored parameters and movements were recorded. If scores of movement were $\geq 2$ in any of these three steps, an additional minute was deferred before the next step. The time from induction of anaesthesia until emasculation, as well as the time from the injection of lidocaine until cut, was recorded. At the end of the castration, the degree of postoperative bleeding $(0=$ no bleeding, $1=$ mild bleeding, $2=$ moderate bleeding) was judged. The piglets were weighted and placed back to the other male piglets. The time from the end of inhalation anaesthesia (taking the mask off the piglet's nose) until full recovery (standing and 4 steps) was measured.

After 24 hours the piglets underwent a pain assessment adapted from Stark (Stark, 2014). For this purpose each piglet was observed during a 10-minute period and events such as playing (seconds), lying (seconds), time at the teats (seconds) and the amount of pain specific behaviour (quantity) were noted (Tab. 2). Additionally the general condition of the piglets was scored by means of a visual analogue scale (VAS; $10 \mathrm{~cm}$ line with $0 \mathrm{~cm}$ $=$ worst possible condition, $10 \mathrm{~cm}=$ good, normal condition).

\section{Statistical analysis}

A power analysis with a power of 0.8 showed, that to test if the incidence of defence movements during castration can be reduced with lidocaine from $50 \%$ to $0 \%$, 11 piglets were considered necessary (WinEpiscope ${ }^{\circledR}$ ). All results were compiled in a spreadsheet (Microsoft Office Excel 2010) and extracted in NCSS 10 (NCSS Statistical Software, Kaysville, USA) for statistical analysis. All continuous parameters were tested for normal distribution. For nonparametric data a Kruskal-Wallis test was used. If significance was obtained, a post hoc analysis with a Mann Whitney U with a manual Bonferroni correction was performed to find the difference between groups. Significance for the incidence of defence movement was tested with a fisher exact test. For this analysis, piglets were either classified as $0=$ no movement, or $1=$ movement during the castration. For scores of defence movement, all scores were summed up from the time-point 1 minute until emasculation and the total score was compared. Statistical significance was considered as $\mathrm{p}<0.05$. For the post hoc analysis $\mathrm{p}<0.017$ was considered significant, as three comparisons were performed.

Table 1: Scoring system used to judge depth of anaesthesia by means of scoring occurring movements during all steps of castration (Berchtold, 2015).

\begin{tabular}{l|l|l} 
Score & Number of movements & Intensity of movement \\
\hline 0 & No movement & No movement \\
\hline 1 & One movement, twitch & Movement of one limb, movement of the head \\
\hline 2 & Repeated movement, $>2$ twitches & Movement of more than one limb, continuous movement of the head \\
\hline 3 & Continuous movement & Same as 2 including vertebral column \\
\hline 4 & & Same as 3, but stronger reaction \\
\hline
\end{tabular}

Table 2: Post operative pain assessment adapted from Stark (Stark, 2014).

\begin{tabular}{|c|c|}
\hline & Non specific behaviour \\
\hline Time at the teats & Time at the teats, suckling, massaging the teats (seconds) \\
\hline Lying & Motionless lying in sternal recumbency, sternum touching the ground (seconds) \\
\hline \multirow[t]{2}{*}{ Playing } & Running, sudden jumping up, animating other piglets (seconds) \\
\hline & Pain specific behaviour \\
\hline Tail movement & Vertical or horizontal movement of the tail, $>3$ movements \\
\hline Pain behaviour & $\begin{array}{l}\text { Kneeling } \\
\text { Scratching (quantity) }\end{array}$ \\
\hline \multirow[t]{2}{*}{ Change of position } & Change in position out of lying or sitting, not counted when induced by another piglet (quantity) \\
\hline & Social behaviour \\
\hline Isolation & $\begin{array}{l}\text { Stay at least two piglet length away from the other piglets. Only counted when desynchronisa- } \\
\text { tion is present (quantity) }\end{array}$ \\
\hline Desynchronisation & Activity distinguishes from at least $75 \%$ of the other piglets (quantity) \\
\hline
\end{tabular}

Optimization of analgesia for piglet castration under isoflurane anaesthesia with parenteral butorphanol, meloxicam or intratesticular lidocaine

P.J. Hug et al. 
Optimization of analgesia for piglet castration under isoflurane anaesthesia with parenteral butorphanol, meloxicam or intratesticular lidocaine

P.J. Hug et al.

\section{Results}

All piglets survived the study. One piglet was euthanized due to inguinal hernia one day after castration. After the first 17 piglets where castrated, 5 piglets showed some of the following unexpected adverse effects: salivation (1), cyanosis (1), dyspnoea (1), vomiting (1), and paddling before (1), during (1) and after (3) castration, as well as excitatory behaviour (2). It was speculated that butorphanol caused these symptoms. The dosage of butorphanol was then adjusted to $0.1 \mathrm{mg} / \mathrm{kg}$ IM. The same adverse effects were present in additional 5 piglets. The person responsible for drug administration revealed, that 10 out of 14 piglets, which received butorphanol, either alone or in combination with meloxicam, experienced side effects, while no piglet out of the other three groups (total of 18 piglets) showed similar symptoms. Therefore, butorphanol was withdrawn from the study after the castration of 32 piglets and the remaining piglets from group $\mathrm{B}$ and $\mathrm{MB}$ were reallocated to the residual three groups. Finally 52 piglets were included in the study, 17 in group M, 18 in group ML4 and 17 in group ML8.

Results are presented with median (interquartile range; range). There was no significant difference between groups in age, estimated weight, scaled weight, time from induction of anaesthesia until emasculation and time from injection of local anaesthesia until cut (table 3). Also no difference was seen between the estimated and the scaled weight of the piglets $(p=0.69)$. EtIso was maintained within predetermined range of $1.8 \pm$ $0.1 \%$ during castration. There was no significant difference in $\mathrm{EtCO} 2$ between the groups at any time point.

In group $\mathrm{M}(11 / 17)$, piglets showed significantly higher incidence of movement than in group ML4 (3/18; $\mathrm{p}=0.01)$ and ML8 (3/17; $\mathrm{p}=0.04)$. Number of defence movements were significantly different, but scores were only significantly different in group $\mathrm{M}(1(0-2.5 ; 4)$ compared to group ML4 $(0(0-0 ; 4), \mathrm{p}=0.012)$, but not to ML8 $(0(0-0 ; 7), p=0.024)$ after the Bonferroni correc- tion. For the intensity of defence movement no significance compared to the control group was obtained after the Bonferroni correction (group M $2(0-3 ; 6)$, group ML4 $0(0-0 ; 6), p=0.018$, group ML8 $0(0-0 ; 10)$, $\mathrm{p}=0.025)$. The vital parameters $\mathrm{HR}, \mathrm{RR}, \mathrm{SpO}_{2}$ and MAP were not significantly different between groups at any time point.

There was no significant difference between groups regarding degree of postoperative bleeding or time until full recovery (Tab. 3). The effectively used dose (based on the scaled weight) of lidocaine in group ML4 was $3.852 \mathrm{mg}(3.15-4.286 ; 3.235)$ and in group ML8 $8 \mathrm{mg}$ (6.667-8.421; 6.956). No adverse effects of lidocaine were seen. No significant difference was seen in the VAS between groups. As the results of the postoperative behaviour assessment were inhomogeneous with wide distributions and the assessment method retrospectively did not seem appropriate, no more details are shown.

\section{Discussion}

As with the current Swiss standard anaesthesia for piglet castration with isoflurane and meloxicam $14-34 \%$ of piglets show purposeful movement in response to surgery (Enz et al., 2013; Steigmann, 2013), the current study investigated further analgesics in order to reduce unnecessary suffering of piglets undergoing castration. In the present study, the additional use of IT lidocaine reduced pain-related defence movements during castration under inhalation anaesthesia from $65 \%$ to $17-18 \%$ independent of dose rate $(4 \mathrm{mg} / \mathrm{kg}$ and $8 \mathrm{mg} / \mathrm{kg}$ ) used. Incidence of movements of group $\mathrm{M}$ in the present study was higher than previously published (Enz et al., 2013; Steigmann, 2013). This discrepancy may have occurred, as the authors of the present study recorded any kind of movement and the piglets were not restrained at all, whereas other authors judged mild movements as unconscious reflexes and not pain related and piglets were fixed with a commercially available castration system. The results of our study are in agreement with previous

Table 3: Age, estimated weight, scaled weight, time from induction of anaesthesia until emasculation, time from injection of local anaesthesia until cut, time until full recovery and amount of post operative bleeding of group M, ML4 and ML8. Numbers are given as median (interquartile range; range).

\begin{tabular}{|l|l|l|l|l} 
& Group M & Group ML4 & Group ML8 & p-value \\
\hline Age (days) & $9(8-9 ; 1)$ & $9(8-9 ; 1)$ & $9(8-9 ; 1)$ & 0.39 \\
\hline Estimated weight $(\mathrm{kg})$ & $3(2-4 ; 4)$ & $3(2.5-3.5 ; 3)$ & $3.5(2.5-3.5 ; 3)$ & 0.96 \\
\hline Scaled weight $(\mathrm{kg})$ & $3.2(2.35-3.5 ; 3.5)$ & $2.9(2.7-3.8 ; 3.2)$ & $3.3(2.8-3.7 ; 1.8)$ & 0.76 \\
\hline $\begin{array}{l}\text { Time induction } \\
\text { anaesthesia - emasculation (sec) }\end{array}$ & $420(373-439.5 ; 190)$ & $379(359-410 ; 184)$ & $410(384-450: 239)$ & 0.27 \\
\hline Time injection lidocaine - cut (sec) & $125(112.5-138 ; 31)$ & $120(115-129 ; 154)$ & $120(115-150: 110)$ & 0.80 \\
\hline $\begin{array}{l}\text { Time until full recovery (sec) } \\
\text { Postoperative bleeding }\end{array}$ & $142(103-182 ; 212)$ & $180.5(116-220 ; 376)$ & $181(143-225 ; 334)$ & 0.74 \\
\hline
\end{tabular}


studies that showed a beneficial analgesic effect of IT lidocaine for piglet castration (Hansson et al., 2011; Kluivers-Poodt et al., 2012). Studies with procaine however concluded, that local anaesthesia was not beneficial for piglet castration, as increased cortisol concentrations thereafter were detected (Zöls, 2006; Zankl et al., 2007). The administration of procaine IT to conscious pigs was additionally deemed painful (Rittershaus, 2009). Therefore, in the present study, IT lidocaine was applied only under inhalation anaesthesia. Lidocaine is rapidly distributed to the spermatic cord when administered IT and reaches peak concentrations at effect site 3 minutes after injection in piglets (Ranheim et al., 2005). In the present study median time necessary from injection of lidocaine until start of castration was 120 seconds. Therefore we recommend to wait at least 2-3 minutes from lidocaine injection to castration. Plasma concentrations of lidocaine of $40 \mathrm{mg} / \mathrm{L}$ induce toxic effects in newborn piglets (Satas et al., 1997). In our study with 8 $\mathrm{mg} / \mathrm{kg}$ lidocaine no toxic effects were observed and the application of either dose tested IT is considered safe.

Anaesthesia induction was performed with a fresh gas flow of $2 \mathrm{~L} / \mathrm{min} \mathrm{O} 2$ and $5 \%$ isoflurane vaporizer setting, which is the dose used in the commercially available inhalation anaesthesia devices. In piglets $1 \mathrm{MAC}$ isoflurane is $1.4 \%$ EtIso (Lerman et al., 1990). MAC is the number at which $50 \%$ of test animals do not react with purposeful movement to a defined stimulus (Eger et al., 1965). In humans the concentration of inhalant at which $95 \%$ of patients would not react to a surgical incision, is 5-40\% higher than 1 MAC (de Jong and Eger, 1975). For this reason we chose to provide 1.3 MAC, which corresponds to $1.82 \%$ EtIso for maintenance of anaesthesia during castration, which has been described to result in a sufficient plane of anaesthesia for a surgical stimulus in pigs (Hodgson, 2006).

The administration of butorphanol led to adverse effects and was therefore withdrawn from the study. To date, pronounced adverse effects of $0.2 \mathrm{mg} / \mathrm{kg}$ butorphanol, as noted in the present study, have not been reported in piglets. Nussbaumer et al. (2011) described mild excitatory behaviour in some cases during induction of anaesthesia using a combination of ketamine, azaperone and butorphanol IM for castration in pigs of different ages. Bettschart-Wolfensberger et al. (2013) reported paddling in two out of 28 nine weeks old pigs receiving azaperone, butorphanol, ketamine and meloxicam. None of these authors related these side effects to butorphanol. As the described symptoms in the present study appeared in piglets that had not received any other drug, we suspected butorphanol to be the cause and therefore first re- duced the dose and then withdraw butorphanol from the study. The symptoms were not observed again thereafter. Contradictory to that, Courboulay et al. (2015) used butorphanol $(0.1 \mathrm{mg} / \mathrm{kg})$ in combination with meloxicam for castration of awake French piglets and did not report any adverse reactions. Genetic varieties could explain the discrepancy. In a separate study we investigated parallel to the present study the effect of butorphanol $(0.2 \mathrm{mg} / \mathrm{kg} \mathrm{IM})$, it clearly showed, that butorphanol causes restlessness, vocalization and panting, as well as excitatory behaviour (Cap et al., 2017). In other species adverse effects of butorphanol are well described. While dysphoric behaviour is described in cats (Lascelles and Robertson, 2004), horses become ataxic and have increased locomotion (Sellon et al., 2001; Knych et al., 2013), whereas sheep become dysphoric and ataxic (Waterman et al., 1991). These adverse reactions to butorphanol administration warrant further investigation in piglets.

For the postoperative evaluation 24 hours after castration, the piglets were observed for ten minutes as described by Stark (2014). When the study was designed this was the only pain assessment described for this age category of piglets. It was quickly discovered, that it depended which ten minutes were evaluated. Sometimes these 10 minutes were spent with lying or drinking whereas 10 minutes later the litter was active and played. Some of the pain specific behaviour was also observed in not castrated piglets of the litter and therefore we conclude that the scoring system used was not appropriate to properly detect differences in postoperative pain between the groups. A newly available method to score postoperative pain, the piglet grimace scale, is an alternative that could be implemented in further investigations (Viscardi et al., 2017).

The authors conclude, that for castration of 7-14 days old piglets under isoflurane anaesthesia and parenteral meloxicam, perioperative analgesia is optimised by additional application of IT lidocaine. For optimal results at least two minutes have to elapse between local anaesthesia application and castration. No toxic side effects were seen and it is concluded that lidocaine $8 \mathrm{mg} / \mathrm{kg}$ can be used safely in daily practice.

\section{Acknowledgement}

The authors would like to thank Simone Ringer for the advices in the final phase the study as well as Samuel Ritter for the good care he took of the piglets of the experiment.
Optimization of analgesia for piglet castration under isoflurane anaesthesia with parenteral butorphanol, meloxicam or intratesticular lidocaine

P.J. Hug et al. 
Optimization of analgesia for piglet castration under isoflurane anaesthesia with parenteral butorphanol, meloxicam or intratesticular lidocaine

P.J. Hug et al.

\section{Optimisation de l'analgésie lors de la castration des porcelets sous anes- thésie à l'isoflurane par I'utilisation de méloxicam et de butorphanol ou par l'injection intra-testiculaire de lidocaïne}

Cette étude prospective en aveugle étudie l'effet analgésique de l'injection intramusculaire (IM) de butorphanol et de méloxicam ou de l'injection intra-testiculaire (IT) de lidocaïne pour la castration, sous anesthésie à l'isoflurane, de porcelets âgés de 7 à 14 jours. Soixantesix porcelets ont reçu de manière aléatoire soit du méloxicam IM ( $0.4 \mathrm{mg} / \mathrm{kg}$; groupe $\mathrm{M})$, soit du butorphanol IM $(0.2 \mathrm{mg} / \mathrm{kg}$; groupe B), soit les deux substances (groupe MB) 20 minutes avant la castration, soit de la lidocaïne IT (4 mg/ $\mathrm{kg}$ (groupe ML4) ou $8 \mathrm{mg} / \mathrm{kg}$ (groupe ML8)) ainsi que du méloxicam IM $(0.4 \mathrm{mg} / \mathrm{kg})$, avec une anesthésie à l'isoflurane à $1.8 \%$ en fin d'expiration. Les fréquences cardiaques et respiratoires, la pression artérielle moyenne et le $\mathrm{CO} 2$ en fin d'expiration ont été documentés. La qualité de l'anesthésie a été estimée et le comportement post-opératoire observé. Le butorphanol a causé des effets secondaires inacceptables et son usage a été stoppé. Le groupe $\mathrm{M}$ montrait une plus mauvaise qualité d'anesthésie que les groupes ML4 et ML8 (plus grande incidence de mouvements : 11/17, 3/18 et 4/17). Les autres paramètres intra opératoires ne présentaient pas de différences significatives et on a pas constaté de différences entre les groupes dans la phase postopératoire. Pour la castrations de porcelets âgés de 7 à 14 jours sous anesthésie à l'isoflurane, l'utilisation intra testiculaire de lidocaïne représente une analgésie supplémentaire dépourvue d'effets secondaires.

\section{L'ottimizzazione dell'analgesia per la castrazione dei suinetti via l'ane- stetico isoflurano con parenterale butorfanolo, meloxicam o lidocaina intratesticolare}

Questo studio prospettivo in cieco ha analizzato l'effetto analgesico di butorfanolo per via intramuscolare (IM), meloxicam (IM) e lidocaina per via intratesticolare (IT), per la castrazione di suinetti di età tra i 7 e i 14 giorni sotto anestesia per isoflurano. A 66 suinetti randomizzati sono stati iniettati 20 minuti prima della castrazione: meloxicam via IM $(0.4 \mathrm{mg} / \mathrm{kg}$; gruppo $\mathrm{M})$, butorfanolo via IM $(0.2 \mathrm{mg} / \mathrm{kg}$; gruppo B), o entrambi (gruppo MB), oppure lidocaina via IT (4 mg/ $\mathrm{kg}$ (gruppo ML4), o $8 \mathrm{mg} / \mathrm{kg}$ (gruppo ML8)) e meloxicam via IM $(0.4 \mathrm{mg} / \mathrm{kg})$ sotto $1.8 \%$ end-tidal anestesia con isoflurano. Sono state documentate frequenza cardiaca e respiratoria, pressione arteriosa differenziale e anidride carbonica di fine espirazione (end-tidal). La qualità dell'anestesia è stata valutata e osservato il comportamento postoperatorio. Il butorfanolo ha causato effetti collaterali inaccettabili e il suo uso è stato interrotto. Il gruppo $\mathrm{M}$ ha mostrato una peggiore qualità dell'anestesia come i gruppi ML4 e ML8 (maggiore incidenza di movimenti: 11/17, $3 / 18$ e 4/17). Ulteriori parametri intraoperatori non hanno mostrato differenze significative e il comportamento postoperatorio non ha manifestato differenze tra i gruppi. Per la castrazione dei suinetti di età tra i 7 e i 14 giorni sotto anestesia con isoflurano l'aggiunta di lidocaina somministrata via IT ha offerto un'ulteriore analgesia senza effetti collaterali.

\section{Literature}

Berchtold S.: Optimierung der Injektionsanästhesie für die Ferkelkastration. Dissertation, Universität Zürich, 2015.

Bettschart-Wolfensberger R., Stauffer S., Hässig M., Flaherty D., Ringer S. K.: Racemic ketamine in comparison to S-ketamine in combinaiton with azaperone and butorphanol for castration of pigs. Schweiz. Arch. Tierheilk. 2013, 12: $669-675$

Bonastre C., Mitjana O., Tejedor M. T., Calavia M., Yuste A. G. Ubeda J. L., Falceto M. V.: Acute physiological responses to castration-related pain in piglets: the effect of two local anesthetics with or without meloxicam. Animal 2016 9: $1474-1481$

Cap V. H., Abass Mossa M., Hug P. J., D. K., BettschartWolfensberger R.: Butorphanol induces anxiety-like behaviour and distress in piglets. In: Nechvátalová K. and Nathues H. 9th European Symposium of Porcine Health Management (ESPHM), Prague, 2017, 9: 115 .
Courboulay V., Gillardeau M., Meunier-Salaün M.-C., Prunier A.: La prise en charge de la douleur lors de la caudectomie et de la castration des porcelets. In: 47. Journées de la Recherche Porcine, 2015, 47: 235-240.

de Jong R. H., Eger E. I., 2nd: MAC expanded: AD50 and AD95 values of common inhalation anesthetics in man. Anesthesiology 1975, 4: 384-389.

Eger E. I., 2nd, Saidman L. J., Brandstater B.: Minimum alveolar anesthetic concentration: a standard of anesthetic potency. Anesthesiology 1965, 6: 756-763.

Enz, Schüpbach-Regula, Bettschart, Fuschini, Bürgi, Sidler: Erfahrungen zur Schmerzausschaltung bei der Ferkelkastration in der Schweiz Teil 1: Inhalationsanästhesie. Schweiz. Arch. Tierheilk. 2013, 12: 651-659.

Haga H. A., Ranheim B.: Castration of piglets: the analgesic effects of intratesticular and intrafunicular lidocaine injection. Vet. Anaesth. Analg. 2005, 1: 1-9. 
Hansson M., Lundeheim N., Nyman G., Johansson G.: Effect of local anaesthesia and/or analgesia on pain responses induced by piglet castration. Acta. Anaesthesiol. Scand. 2011, 34: $1-9$

Hodgson D. S.: An inhaler device using liquid injection of isoflurane for short term anesthesia in piglets. Vet. Anaesth. Analg. 2006, 4: 207-213.

Hodgson D. S.: Comparison of isoflurane and sevoflurane for short-term anesthesia in piglets. Vet. Anaesth. Analg. 2007, 2: 117-124.

Kluivers-Poodt M., Houx B. B., Robben S. R., Koop G. Lambooij E., Hellebrekers L. J.: Effects of a local anaesthetic and NSAID in castration of piglets, on the acute pain responses, growth and mortality. Animal 2012, 9: 1469-1475.

Knych H. K., Casbeer H. C., McKemie D. S., Arthur R. M.: Pharmacokinetics and pharmacodynamics of butorphanol following intravenous administration to the horse. J. vet. Pharmacol. Therap. 2013, 1: 21-30.

Lascelles B. D., Robertson S. A.: Use of thermal threshold response to evaluate the antinociceptive effects of butorphanol in cats. Am. J. Vet. Res. 2004, 8: 1085-1089.

Lerman J., Oyston J. P., Gallagher T. M., Miyasaka K., Volgyesi G. A., Burrows F. A.: The minimum alveolar concentration (MAC) and hemodynamic effects of halothane isoflurane, and sevoflurane in newborn swine. Anesthesiology $1990,4: 717-721$

Nussbaumer I., Indermuhle N., Zimmermann W., Leist Y.: Piglet castration using injection anesthesia: experiences with a combination of azaperone, butorphanol and ketamine. Schweiz. Arch. Tierheilk. 2011, 1: 33-35.

Petersen-Felix S., Arendt-Nielsen L., Bak P., Roth D., Fischer M., Bjerring P., Zbinden A. M.: Analgesic effect in humans of subanaesthetic isoflurane concentrations evaluated by experimentally induced pain. Br. J. Anaesth. 1995, 1: 55-60.

Ranheim B., Haga H. A., Ingebrigtsen K.: Distribution of radioactive lidocaine injected into the testes in piglets. J. vet. Pharmacol. Therap. 2005, 5: 481-483.

Rittershaus D.: Topische Anästhesieverfahren zur Schmerzreduktion bei der Saugferkelkastration. Dissertation, Tierärztliche Hochschule Hannover, 2009.

Riviere J. E., Papich M. G.: Veterinary Pharmacology \& Therapeutics. In: Veterinary Pharmacology \& Therapeutics. RIviere JE \& Papich MG, Wiley-Blackwell, lowa, 2009, 301-331.

Satas S., Johannessen S. I., Hoem N. O., Haaland K., Sorensen D. R., Thoresen M.: Lidocaine pharmacokinetics and toxicity in newborn pigs. Anesth. Analg. 1997, 2: 306-312.

Schulz C.: Auswirkung einer Isofluran-Inhalationsnarkose auf den Kastrationsstress und die postoperativen Kastrationsschmerzen von Ferkeln. Dissertation, Tierärtzliche Fakultät der Ludwig-Maximilians-Universität München, 2007

Sellon D. C., Monroe V. L., Roberts M. C., Papich M. G.: Pharmacokinetics and adverse effects of butorphanol administered by single intravenous injection or continuous intravenous infusion in horses. Am. J. Vet. Res. 2001, 2: 183-189.

Stark J.: Auswirkungen von Ohrmarken einziehen im Vergleich zu Kastration und Schwanzkupieren und Etablierung einer Verhaltensmethodik zur Beurteilung kastrationsbedingter Schmerzen beim Saugferkel. Dissertation, Tierärztliche Fakultät der Ludwig-Maximilians-Universität München, 2014.
Steigmann M.: Evaluierung der Schmerzausschaltung be der Kastration männlicher Ferkel unter automatisierter Isoflurannarkose. Dissertation, Tierärztliche Hochschule Hannover, 2013.

Vandermeulen E.: [Pain perception, mechanisms of action of local anesthetics and possible causes of failure]. Rev. Belge. Med. Dent. 2000, 1: 29-40.

Viscardi A. V., Hunniford M., Lawlis P., Leach M., Turner P. V.: Development of a Piglet Grimace Scale to Evaluate Piglet Pain Using Facial Expressions Following Castration and Tail Docking: A Pilot Study. Front. Vet. Sci. 2017, 51. doi: 10.3389/ fvets.2017.00051

Waterman A. E., Livingston A., Amin A.: Analgesic activity and respiratory effects of butorphanol in sheep. Res. Vet. Sci. 1991, 1: 19-23

Zankl A., Ritzmann M., Zöls S., Heinritzi K.: Untersuchungen zur Wirksamkeit von Lokalanästhetika bei der Kastration von männlichen Saugferkeln. Dtsch. Tierärztl. Wochenschr. 2007, 11: 418-422.

Zöls S.: Möglichkeiten der Schmerzreduzierung bei der Kastraton männlicher Saugferkel. Dissertation, Tierärtzliche Fakultät der Ludwig-Maximilians-Universität München, 2006.

\section{Corresponding author}

Petra Julia Hug

Section of Anaesthesiology, Equine Department

Vetsuisse Faculty, University of Zurich

Winterthurerstrasse 260

$\mathrm{CH}-8057$ Zürich

Switzerland

Tel +41 (0)78 7250423

E-Mail:phug@vetclinics.uzh.ch
Optimization of analgesia for piglet castration unde isoflurane anaesthesia with parenteral butorphanol, meloxicam or intratesticular lidocaine

\section{P.J. Hug et al.}

